\title{
Streetscape techniques in a water scarce environment
}

\author{
O. S. BaHammam \\ Department of Urban Planning, College of Architecture and Planning, \\ King Saud University, Saudi Arabia
}

\begin{abstract}
Trees and other forms of greenery have been associated with human settlements since the dawn of time. In modern time, Greenery plays a major role in shaping healthy and beautiful cities. They scatter among the urban fabric mostly along public streets. Cities all over the world give serious attention to streetscape in order to overcome the decline of the natural environment as a result of the new industrialized urban growth. Riyadh City, as one of the large metropolitan cities of the world, faces the challenge of developing its streetscapes in a hostile harsh arid environment. The challenge is either to waste scares water resources or to utilize a valuable way of managing water use in order to develop the needed streetscapes that cope with the environmental situation. A sustainable approach is important to be adapted in order to carry on development that saves water, protects resources and fulfills the needs. This study is trying to assess the existing situation of streetscapes in Riyadh, the proper techniques for planting and designing in a desert city. The study will identify appropriate techniques and solutions for existing and future applications. In order to address this research, different research methods were applied to answer the research concerns.

Keywords: planting patterns, streetscape, scares environment, street patterns, arid landscape, draught tolerant plants, irrigation techniques.
\end{abstract}

\section{Introduction}

Throughout the history of mankind, starting from the Assyrians to the Egyptians, open spaces and urban outdoors were part of city and town planning. Elegant cities in the arid Middle East flourished in Greek and Roman civilizations [1]. Arabs carried on the developments, creating new settlements, introducing new 
irrigation techniques utilized for urban use and transferring all of that into Western Europe through Spain [1].

During the booming civilization of the Middle East, the use of trees in public spaces within the urban forms continued in many cities. It was significant in the Circular City of Baghdad, built in the $8^{\text {th }}$ century AD [2], with its central public gardens and in the Turkish City of Bursa in the $15^{\text {th }}$ century $\mathrm{AD}$ [2, p. 71]. In the City of Bursa, a group of public buildings were built in a green landscaped area. Because of the intensive use of trees, the facility was called the "green group" [2].

The utilization of trees in public spaces started in the west with the Baroque gardens of France [3, p. 145]. These gardens consisted of wide pathways radiating from clearing the forest for the purpose of shooting game during the hunt. This concept inspired the radial street pattern of Paris and Washington D.C. [3, p. 150]. The new boulevards of these cities were lined up with trees on their sides.

A real effort to introduce trees to streets began in the early and mid 19th century as a reaction of the negative impacts of industrialization in Europe and America. Classic examples of such efforts were the work of Ebenezer Howard in 1898 that originated the "Garden City" concept [4, pp. 262-263] and Olmsted's urban park projects in several American cities [4, pp. 434-435].

In the City of Riyadh, Saudi Arabia, there are many advantages and challenges in using trees in the urban forms of the city. The city is located in the middle of Arabia, with a unique extreme desert environment. There are many factors challenging the spread of public trees in the city. The major factors are mainly related to water issues, climatic condition, and design and planning situations.

\section{Objective and scope}

The utilization of trees in Riyadh has gone through many stages in the last half of the $20^{\text {th }}$ century. An extensive planting action took place in order to spread trees and greenery in the city [5, pp.35-37]. The spread of greenery in the city was mainly consisted of the use of trees because of their characteristics in influencing and shaping the environment of the city and providing the needed aesthetic values. As a monitoring advantage of this experience, after over 60 years of planting and spreading greenery in the city, here come the primary objective in this paper which is to observe and assess the experience and subtracting the successes of the used techniques in spreading trees and greenery in the streetscape in the extreme arid environment of the City.

The Arid environment is well known by its scarcity of water and high level of evaporation. These characteristics can be specified as the sun and wind influences (high temperature, glare, wind intensity and dust blow. The scarcity of water can be considered either because of the climatic situation or because of the absence of surface water bodies (lakes or rivers). In addition to the mentioned challenges more constrains are presents within the urban fabric. These constrains are the unavailability of enough spaces to accommodate public trees. 
To address the objective a fieldwork survey was used to know the situation of streetscape in the city of Riyadh and assess the influence of challenges facing the city of Riyadh as an example of scarce water environment and what are the techniques and lessons that can be drawn from it in order to overcome those challenges.

In order to conduct an objective survey of the streets of Riyadh, the city was broken into six zones to ease the survey and to simplify the collection of the data. A careful attention was given to ensure coverage of all street categories in order to be able to generalize the study results. The survey was conducted in the midday between 10:00 am and 5:00 pm. A set of criteria was adapted for selecting surveyed streets and surveyed segments (see fig. 1).

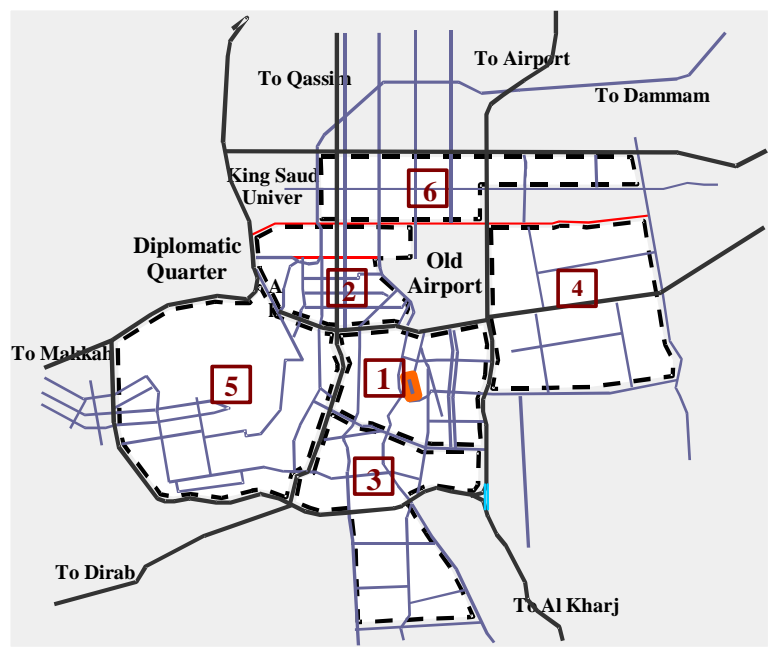

Figure 1: The survey was carried out by breaking the city into six zones.

\section{History of the city}

Riyadh is an old city located in the mid of the vast Arabian peninsula desert. It represented the romantic prototype of a desert oasis. William Palgrave, the famous British traveler who reached the city in 1863, tried to convey a picture of the city and its surroundings:

"Before us stretched a wide open valley, and in its foreground, immediately below the pebbly slope on whose summit we stood, lay the capital, large and square, crowned by high towers and strong walls of defense. .... All around for three miles over the surrounding plain, but more especially to the west and south, waved a sea of palm-trees above green fields and well-watered gardens” [5, pp. 228-229].

In fact the name Riyadh was derived from the extensive greenery of the city and it means in the Arabic language "Gardens". With the expansion of the city at the beginning of the last century, the city spread over its traditional surrounded palm tree gardens. The new urban areas of the city represent a completely 
different land subdivision and street layout from the compact traditional one. This new pattern of streets was based on the grid pattern, which is usually comprised of equally spaced streets at right angles. Dwellings are lined up equally along these streets. To define the function between streets that were designed for automobiles and the dwellings on their sides, narrow sidewalks were built on the edges of most streets.

In order, for the city authorities, to overcome the negative image of the city resulted from the extensive expansion of housing developments; they got committed to restore the lost greenery by increasing the presence of trees on the newly developed urban areas. . The easiest and most logical way to do so, in a city like Riyadh, was to use the remaining public domains of streets (side-walks and middle-islands) (see table 1).

Table 1: $\quad$ Patterns of streets in the City of Riyadh.

\begin{tabular}{|c|c|c|}
\hline Pattern & Street Widths & Street Shape \\
\hline - $\quad$ Highway & $>100 \mathrm{~m}$ & П几几 \\
\hline - $\quad$ Main Road & $60-80 \mathrm{~m}$ & 几ـ几 \\
\hline - $\quad$ Main Street & $40-60 \mathrm{~m}$ & Пـــــ \\
\hline - Distributor Street & $20-40 \mathrm{~m}$ & 几ـــ \\
\hline - $\quad$ Local Street & $<20 \mathrm{~m}$ & $\sqcap$ \\
\hline
\end{tabular}

In the mid-1980s, the city established a department in the municipality to lead and supervised the intensive work that took place. A major fault of the newly established department was that it had not kept the detailed records of the planting projects conducted by their crews nor by their field contractors. Due to that, little information regarding date, process, plant species and cost of planting of each street and/or areas of the city are existed in hand.

\section{Existing patterns and situation of streetscape}

In the contemporary urban pattern there are differences in street sizes and shapes. As a result of these differences, planting programs vary in the distributions and species of planting. Different planted stages also affected the results and the outcomes. The field survey and archival search revealed the following patterns that can be discussed in the following sections in relation to distribution and selection of planting on streets. Study revealed four patterns of streetscapes. These patterns are as follows.

\subsection{First pattern - local and distributed street}

Local and distributor streets consist of trees planted in their paved sidewalks adjacent to the private property's external walls (see fig. 2). 

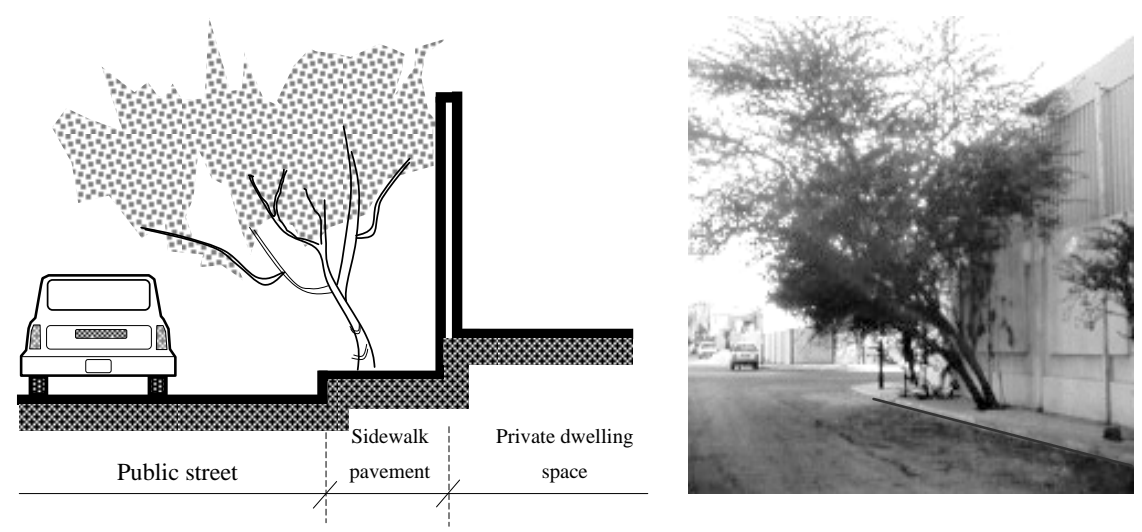

Figure 2: Conceptual illustration of the detected planting pattern of the local and distributed streets.

\subsection{Second pattern - main street}

Main streets consist of trees planted on the sidewalks and the middle island pavement (see fig. 3).

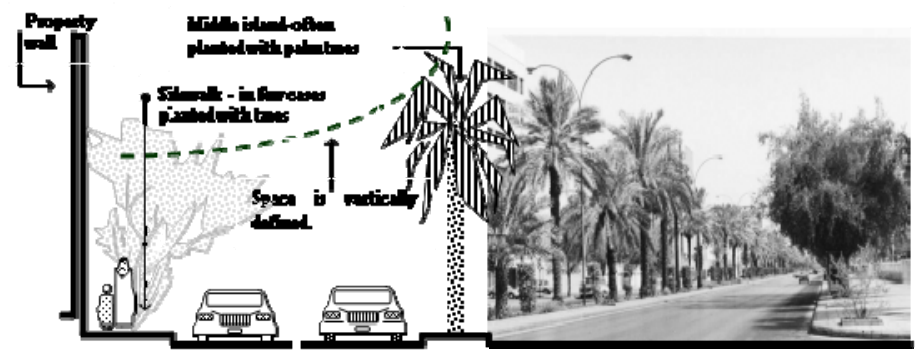

Figure 3: Conceptual illustration of the detected planting pattern of the Main streets.

\subsection{Third pattern - main road}

Main roads consist of trees planted on the main middle island separating the two opposite traffic directions of the road and on the secondary middle islands separating the main traffic lanes from the service lanes of each direction (see fig. 4).

\section{Distribution of tree species for streetscape}

A review of planting from the early attempts to present time shows that planting street trees can be classified into three main stages. Each stage has its own characteristics and identity. These stages are as follows: 
The first stage consists of streets planted before the 1980s. This stage was characterized by the exclusive planting of native tree species. The two most used species in that stage were Phoenix dactylifera and Zizyphus spina christi. They were used mainly because they were well known species for the municipality's planting teams at that time. Palm trees (Phoenix dactylifera) were mainly planted in the middle islands of important streets at that time, such as in the Airport Street \& the University Street (see fig. 5).

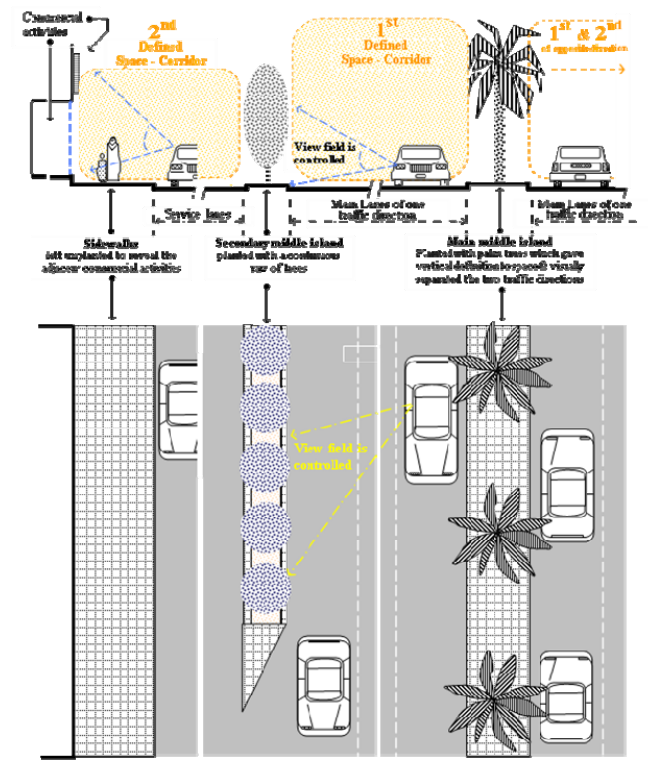

Figure 4: Conceptual illustration of the detected streetscape pattern of the main roads.

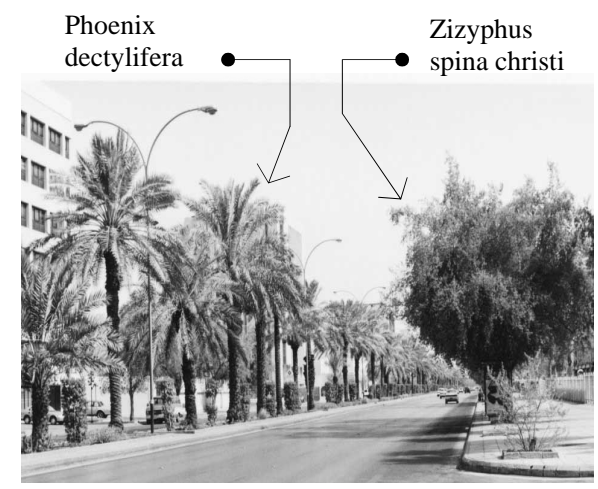

Figure 5: Examples of streets planted with Phoenix dactylifera trees in the middle island and Zizyphus Spina trees on the sides. 
The second stage consists of streets planted between the 1980s and 1990s. In this stage, planting gained momentum due to the expansion of the city and the awareness of the importance of trees for health and beautification of the urban environment $[4, \mathrm{p} .36]$. The main characteristics of this stage were:

(a) the dependence on the non-native (imported) tree species;

(b) planting reached about $58 \%$ of the city streets; and

(c) planting trees in paved sidewalks as well as on middle islands of different sizes and categories of streets (see fig. 6).

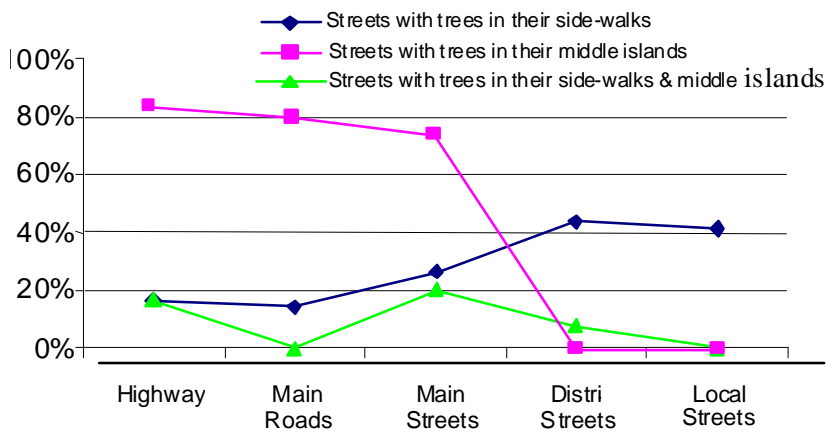

Figure 6: $\quad$ Streets with trees in their side-walks, middle island(s) and in both side-walks and middle island(s).

Prosopis was the most popular tree planted on streets during the second stage (as in fig. 7). It was used in almost $70 \%$ of the planted streets. Few other imported tree species were used also during this stage. Table 2 presents the most common tree species used.
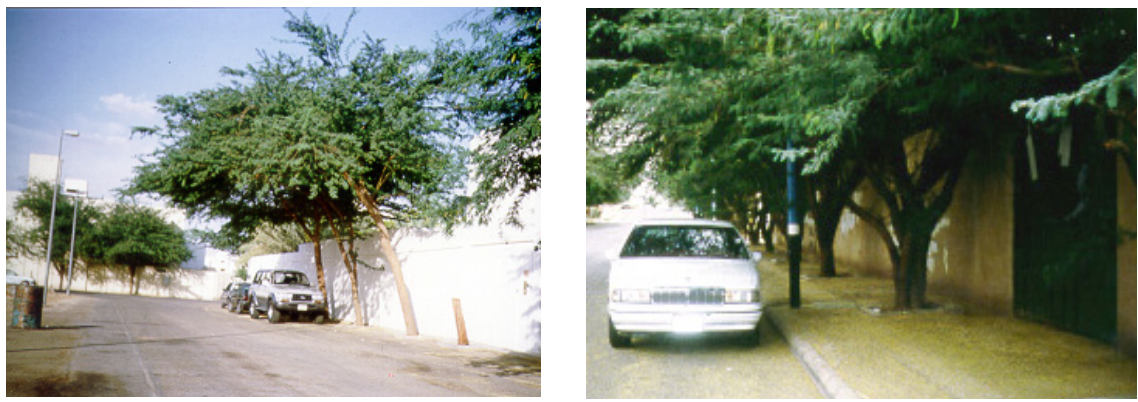

Figure 7: Two samples of street planted with Prosopis trees during the second stage.

The third stage consists mainly of management and maintenance work. Since the beginning of 1990s, few new streets were planted with trees, and in general few changes have occurred to the existence of trees on the streets. Planting in this stage consisted of a steady process of replacing damaged and/or improper 
located trees. The Conocarpus erectus tree has replaced many Prosopis and Eucalyptus trees. This tree specie has been successfully planted in the city in the last 15 years. It proves to be suitable for street planting because of its upright oval head and extremely fast-growth. The major problem with this specie is that it has an aggressive root behavior, produces unpleasant smell in the blooming season and requires frequent maintenance and cleaning.

The dependence mainly on one plant specie represents a very critical risk for the planting program. In many incidents in the past, when a certain disease attacked some plant species, it destroyed them or as it once happened when the temperature rose above normal, certain species died. Such incidents destroy the greenery on a mass scale and lead to a big economic and environmental loss. Therefore, It has become a standard practice in the profession to diversify the plant selection used in cities. The existing situation, as it is right now, puts the planting program in the city at risk because of the dependence on two main species, Prosopis spp in the second stage and Conocarpus lately.

Table 2: $\quad$ Percentages of different tree species planted on streets.

\begin{tabular}{lc}
\hline Name of trees & $\begin{array}{c}\text { \% of tree specie planted } \\
\text { on streets }\end{array}$ \\
\hline Prosopis spp. & $69.7 \%$ \\
Pithecellobium dulce & $38.5 \%$ \\
Ficus religiosa & $6.4 \%$ \\
Delonix regia & $5.5 \%$ \\
Albizia lebbek & $3.7 \%$ \\
Eucalyptus sergeant & $3.6 \%$ \\
\hline
\end{tabular}

\section{Dealing with the scarcity of water}

Although the city name is Riyadh, which means gardens, but still it is a desert city lacking greenery. Authorities of the city recognized this problem since the early stages the contemporary city expansion. They utilized some of the city features and tried to avoid some of its faults to overcome the scarcity of water and the lack of greenery.

One of the advantages of the nature of the city is the formation of the stone layers underneath it. The city has several sold sedimentary rock layers 1-2 meters under the top soil that hold the rain water and the leakages of the public water piping system [4]. These stone layers work as traps for water and protect it from soaking deep to ground or evaporation in the hot and dry climate. This advantage explain why the city was named "gardens" and why William Palgrave described it the way he did (see fig. 8). The authorities of the city utilized this resource very well by locating these trapped water and used them in watering the intended greenery.

In general, we can confidentially confirm that the city has overcome the obstacles of the scarcity of water and the harshness of the climatic conditions in order to spread greenery by utilizing fours unique solutions and/or techniques. 
These solutions and/or techniques are:

1.Planting native or drought tolerant plant species.

2.Relaying on tree form plants in most of its planting projects, for their characteristics in consuming less water.

3.Applying modern water conserving techniques such as drip irrigation systems throughout the city's planting projects.

4.Utilizing the trapped water near the surface for irrigation.

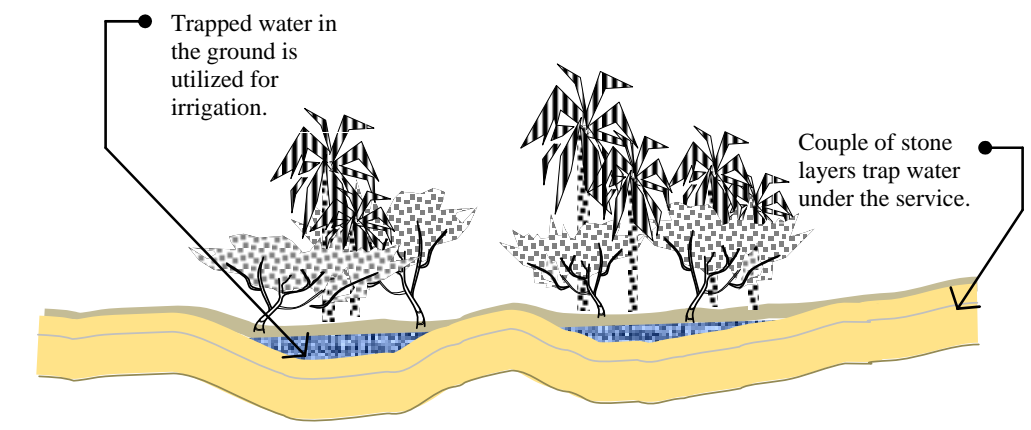

Figure 8: A couple of stone layers trapping water that is utilized for irrigation.

\section{Conclusion and discussion}

Although there has been no specific formal planting program, Riyadh City has gone through extensive planting stages to spread greenery in the city. After almost six decades of planting, the paper tried to assess the existing situation of streetscapes, the proper used techniques for planting and designing in desert city. The study will identify appropriate techniques, methods and designing ideas for existing and future applications.

Planting trees in Riyadh has gone through many stages in the last half of the 20th century. The spread of greenery in the city was mainly consisted of the use of trees because of their characteristics in influencing and shaping the environment of the city and providing the needed aesthetic values and climatic benefits.

As a monitoring advantage of this experience, after over 60 years of planting and spreading greenery in the city, here come the primary objective in this paper which is to observe and assess the experience and subtracting the successes of the used techniques in the process of streetscape in the extreme arid environment of the City.

The aridity of the environment did not stop the progress that took place in landscaping the city; therefore, a fieldwork survey was used to know the situation of streetscape in the city and to learn out how authorities overcame the stresses of the environment and the constrains of the tightness of the urban fabric. 
The field survey revealed the following patterns implemented in the streetscape of the city. These detected patterns are:

1. Planting sidewalks of local and distributor streets. In this pattern planting usually relayed on native or draught tolerant trees.

2. Planting main streets consist of using sidewalks and middle island. In this pattern, the use of palm trees can be obvious on the middle island.

3. Planting main roads consist of using the main middle island and the secondary middle islands. In this pattern, the use of palm trees in the middle and small size trees on the secondary middle islands.

A review of planting from the early attempts to present time shows that streetscape planting can be classified into three main stages which took place. Each stage has its own characteristics and identity. These stages can be categorized as:

1. Relaying on native plants especially trees (this was during the $1^{\text {st }}$ stage).

2. Depending on the non-native, but draught tolerant plant species especially trees in streetscape planting projects (this was during the $2^{\text {nd }}$ stage).

3. Managing the existing planted streets with no clear vision as in the previous two stages.

As one conclusion of the study, the most fruitful stage and the most successful one is the second stage. The use and the utilization of the imported (non-native) trees in the planted program gave more variety and discovered better and more appropriate plant species for streetscape in the city. Many of the native trees have a very aggressive root behavior, due to their desert nature, which badly affecting the underground infra-structure within the urban fabrics. Many of these non-native species proved to be a good choice for streetscape with a very good tolerance to the existing environmental stresses.

In regarding to water scarcity, the city authorities successfully utilized one of the natural features that can be a nightmare for infra-structure in the city which is the trapped water near the ground surface for irrigation of streetscape planting. This idea overcame the scarcity of water in the city and allows for providing the needed water. In dealing with the shortages of water, the city authorities relayed on several solutions. These are:

1. Using native or drought tolerant plant species.

2. Relaying on trees in most of its planting projects, for their characteristics in consuming less water.

3. Applying drip irrigation systems throughout planting projects.

4. Utilizing the trapped water near the service for watering.

Finally, this study took a step forward to highlight some of streetscape issues in a water scares environment. It is believed that the topic is worth the effort especially when dealing with a multi profession issue such as streetscape in a large metropolitan city such as Riyadh. Further studies are needed to be done to cover more related issues that this study could not cover in order to come out with a complete vision in regard to proper implementations and designs for planning city streets. 


\section{References}

[1] Pregill, Philip and Volkman, Nancy, Landscapes in History, Design and Planning in the Western Tradition, Van Nostrand Reinhold: New York, 1993.

[2] Abdul Rahman, Abdullah, "Altarweeh in the Arab Cities," In the sixth symposium of the Arab Cities Organization, the Institute for Developing the Arab Cities: Al Doha, Qatar, 1980.

[3] Zube, E. H, "Trees and Woodlands in the Design of the Urban Environment.” Trees and Forest in an Urbanizing Environment. Planning Research Development Service. No. 17, University of Massachusetts Press: Amherst, Massachusetts, 1971.

[4] Municipality of Riyadh, Al Tashjeer wa al Tajmeel fi Madinat al Riyadh (in English: Greening and Beautification of the City of Riyadh) Municipality of Riyadh, Riyadh, Saudi Arabia, 1990.

[5] Palgrave, W. G., Personal Narrative of a Year's Journey through Central and Eastern Arabia, McMillan, London, 1868.

[6] Hough, M, City Form and Natural Process: Toward a New Urban Vernacular, Routledge, London and New York, 1989.

[7] Bradshaw, A., Hunt, B. \& Walmsley, T., Tree in the Urban Landscape: Principles and Practice, E \& FN Spon, London \& New York, 1995.

[8] Zion, Robert L., Trees for Architecture and Landscape, Van Nostrand Reinhold, New York and London, 1995.

[9] Krieg, J. C., Sappington, N. R. H. and Sappington, C., Desert Landscape Architecture, CRC Press, New York, 1999.

[10] Al Zagt, M. F. Dallel Z., al Nabatat fi Mantagat al Riyadh. (in English: Guide to Planting in Riyadh Region), King Saud University, Riyadh, Saudi Arabia, 1989. 